Jurnal Pendidikan Bahasa Inggris Proficiency, Vol 4 No 1 Jan 2022

\title{
THE IMPLEMENTATION OF TOTAL PHYSICAL RESPONSE (TPR) METHOD TO TEACH VOCABULARY IN E-LEARNING
}

\author{
Noviya Lakshita Dewi, Ayu Fatmawati \\ noviyalakshita20@gmail.com, ayu@uniska-kediri.ac.id
}

\begin{abstract}
This research was starting from the researchers' case about learning vocabulary for young learners who have to face the digital era, especially in the Pandemic era Covid 19. The researcher investigated one of suitable method for teaching vocabulary to young learners, which is called TPR. For this reason, the researcher wants to see the teaching of vocabulary to young learner using TPR. This research is a qualitative descriptive research. The subjects of this research are the owner of English Box Course, a vocabulary tutor and learners. Data collection in this research was carried out in three ways, namely: observation, interviews, and documentation and using three instruments there are observation checklist, interview guide, and list of documentation. Data analysis was carried out according to theory Miles and Hubermen, namely: data reduction, data display, and verification. The results of this research is explained into three parts: 1) The implementation of Total Physical Response (TPR) method in the term of planning, process and evaluation of teaching vocabulary through E-Learning: a) There are two steps in the planning, those are make a lesson plan and media preparation. $b$ ) The process of implementation of Total Physical Response (TPR) method to teach vocabulary in E-Learning is started with apperception. c) The evaluation is taken in general of learning-teaching process that aims to make sure understanding of the students. 2) The implementation of Total Physical Response (TPR) method in teaching vocabulary through $\mathrm{E}$-Learning produce exciting and enjoyable response of two students. 3) It is conducted oral and movement assessment test of the implementation of Total Physical Response (TPR) method in teaching vocabulary through E-Learning.
\end{abstract}

Keywords : Total Physical Response (TPR), Vocabulary, E-Learning.

\section{INTRODUCTION}

The learners have to learn speaking as one of the skills in ELT. However, according to (Al Hosni, 2014) some of the students often find difficulties in revealing their ideas in oral communication. August et al. ( as cited in (Astutik \& Aulina, 2017) express that foreign language learners who has limited vocabulary take more time to learn new vocabulary items and are less able to comprehend the text and lack involvement in oral communication with their peers. As a result, such learners are more likely to get lower achievement in language learning assessments and are at the edge of the risk of being indicated as disabled in learning. Based on several theories above, researcher looked at the fact that many students who thinks 
vocabulary is a lesson that is not very important to learn, so students do not have much vocabulary and hinder students' ability to speak. Thus, vocabulary is very crucial in the process of learning a language.

According to Thornbury (as cited in (Al Hosni, 2014), without grammar, very little can be conveyed, without vocabulary, nothing can be conveyed. By mastering a variety of vocabulary in English, students will find it easier to express what is in their minds orally. Thus, teaching vocabulary, especially the way to teach it, becomes an interesting topic to discuss among English teachers. Actually, many teaching methods appeared to help the tutor and learner in the teaching-learning activity in the English teaching and learning process in vocabulary. The learning method is important to master because it is a tool to achieve a goal. One way to develop English vocabulary is using the Total Physical Response (TPR) method.

Total Physical Response (TPR) method was developed by Asher, a psychology professor at the University of San Jose California who has been successful in developing this method in foreign language learning in children. $\mathrm{He}$ argues that direct pronunciation to a child or student contains a command, and then the child or student will respond physically before they start to produce a verbal or verbal response. Asher (in (Larsen-Freeman \& Anderson, 2013) notes that children, in learning their first language, listen more before they speak. This listening activity is accompanied by physical responses such as reaching, seizing, moving, seeing, and so on. This TPR method is very easy and light in terms of language use and also contains elements of game movements so that it can relieve stress on students because of the problems faced in their lessons, especially when learning foreign languages, and can also create a positive mood in students. which can facilitate learning so as to increase student motivation and achievement in these lessons. The meaning or meaning of the target language is learned during the action.

According to Richard J (as cited in Sayd et al., 2018), the total physical response (TPR) method is a language learning method that is structured on the coordination of commands, speech and action, as well as trying to teach language through physical activity (motor). Meanwhile, according to Larson-Freeman ( as cited in Apriliyanti et al., 2019) Total Physical Response (TPR) is a language teaching method built around the coordination of speech and action; it attempts to teach language through physical (motor) activity. Larsen and Diane, total physical response (TPR) is also called "the comprehension approach" or an understanding approach, a method of approaching a foreign language with instructions or commands.

The previous research from (Astutik \& Aulina, 2017), it proves that the TPR method is the right way to be used by English teachers not only in teaching the subject matter of learning English in the classroom but also in interacting and communicating everyday. It can be concluded that the TPR method is a method used for language teaching, especially for teaching vocabulary, where students are asked to understand the vocabulary through physical activity.

Vocabulary is one of the language aspects which should be learnt. Learning vocabulary is important because we are able to listen, speak, read, and write very well. Not only knowing vocabulary but also we have to know the meaning. According to John (2000), "vocabulary is knowledge involves knowing the 
meanings of words and therefore the purpose of a vocabulary test into find out whether the learners can match each word with a synonym, a dictionary-tape definition, or an equivalent word in their own language". So, based on the statement by John, the researcher concludes that vocabulary is very important to support learners' ability in communication, because they can use certain vocabulary in their language appropriately. By using appropriate vocabulary, learner can develop their language skills.

Soedjito et al As cited in (Al Hosni, 2014), vocabulary is the group / richness of words that are owned by a language. Learning a language means learning vocabulary, and it cannot be separated, because vocabulary has main role in determining the fluency of communication. Communicating can be through various languages, including English. The existence of vocabulary in English is one of the requirements for mastering English. Mastery of English can be improved by mastering vocabulary well because good vocabulary mastery will affect one's language skills. Tarigan (in Bari', 2003) states that the quality of a person's language skills clearly depends on the quantity and quality of his vocabulary.

Besides, there are other factors that support the success of vocabulary learning, especially in the Era of the Covid 19 pandemic. According to (Herliandry et al., 2020) online learning provides convenience in providing information transfer in various situations and conditions. Therefore, online learning in which better known as E - Learning will help student to learn

The term of E-Learning contains a very broad meaning, so that many experts describe the definition of E-Learning from various points of view. Rusman ( as cited in Chandrawati, 2010) states that "E-Learning is defined as a web technology application in the world of learning for an educational process". Internet technology makes it easy for anyone to get any information from anywhere and anytime easily and quickly. Meanwhile, according to Jaya Kumar C. Koran in Rusman (as cited in Chandrawati, 2010)), "E-Learning is learning that uses electronic circuits (LAN, WAN, or the internet) to convey the contents of learning, interaction or guidance". The term "e" or an abbreviation of electronics in E-Learning is used as a term for any technology used to support teaching efforts through electronic technology of the internet, intranet, satellite, audio / video tape, interactive TV and CD-ROM are some of the media. The electronics used for teaching may be delivered synchronously (at the same time) or asynchronously (at different times). The teaching material conveyed through this media has text, graphics, animation, simulation, audio and video. Based on the research, the tutor used ZoomMeetng for teaching-learning process.

Based on the explanation above $\mathrm{E}$ - Learning is the media which has many benefits, especially in pandemic Era. E- learning makes learning and teaching process easy, so that the learner and the tutor could give and take the knowlegde.

\section{METHOD}

The research design used is qualitative descriptive research method.. Therefore, the reason this research choosing qualitative descriptive as a method is because the qualitative approach is expected to be able to produce in-depth descriptions of speech, writing, or behaviour that can be observed from certain 
individuals, groups, communities or organizations. The used of qualitative descriptive research design in this research is intended to describe and analyze the implementation of Total Physical Response (TPR) to teach method to teach vocabulary in E-Learning.

The setting of this research conducted at English Box Course, which is located in Pare, Kampung Inggris, Kediri District. In English Box Course, Jl. Masjid 429 Ds. Jambu, Kec. Kayen Kidul - Kediri. In English Box Course, there are three kinds of classes, and those are regular class, private class and English for kids. In English box, the course had only one class for English for kids and the student were three. So that the researcher chooses English for kids class because it is in accordance with the researcher's target. So, the participants in this research are the owner as the informan, the student in the class and the tutor. The instruments that was used by the researcher included:

\section{a) Observation}

The researcher used the observation method to find and collect data according to facts. The researcher used observation checklist. The researcher observed the learning-teaching process toward The Implementation of Total Physical Response (TPR) method in teaching vocabulary through Zoom meeting and how the teacher assess the student.

\section{b) Interview}

The researcher used interview guide during the interview process is in the form of questions to be asked to research subjects that aim to gather as much information as possible about what is related to the problem. The questions prepared are in the form of a standard set of questions with the same order of questions, words, and presentation for each subject. The interview questions were made with the guidelines that the researcher had made. The researcher will interview students of English for kids to find out the students' response, and English teacher to find out the process of implementation of Total Physical Response (TPR) method, from teacher's planning, implementation, assessment and evaluation. The researcher also will interview the owner to make triangle data.

\section{c) Documentation}

This research requires some data. The research data source is divided into two, the primary data source and the secondary data source, which data source in this research was primary data and secondary data. Primary data is obtained from observations, interviews with tutors and learners. The researcher took representative of the learner and the teacher as an informant to get the data. The secondary data of this research was in the form of the lesson plan and the result of assessment from the tutor.

Data analysis in this research used the Miles and Huberman technique. There are three steps of analyze data, those are data reduction, data display, and drawing conclusion. Then the researchers used triangulation data. Susan Stainback (in Sugiyono, 2012) states that the purpose of triangulation is not to find the truth but to increase researchers' understanding of what has been researched. 
Jurnal Pendidikan Bahasa Inggris Proficiency, Vol 4 No 1 Jan 2022

\section{RESULTS AND DISCUSSIONS}

Results and discussions focused on the research focus. There are: (1) the implementation of Total Physical Response (TPR) teaching method to teach vocabulary in E-Learning in terms of planning of teaching vocabulary, the process of teaching vocabulary and the evaluation of implementing TPR teaching method to teach vocabulary in E-Learning; (2) the young learner's response in implementing Total Physical Response (TPR) teaching method to teach vocabulary in E-Learning; (3) how the way the tutor asses the learner.

\section{1) The Implementation of Total Physical Response (TPR) method to teach vocabulary in E-Learning}

There were three steps in the implementation of Total Physical Response (TPR) to teach vocabulary in E - Learning, namely: a) Planning; b) Process; and c) Evaluation.

\section{a. Planning}

There are two activities in the planning, there are; the first activity is to make lesson plan. The function of the lesson plan was a reference for teachers to carry out teaching and learning activities so that they were more focused and run efficiently. The lesson plan used in learning vocabulary aims to adjust to the needs of students. Based on the observation at English Box Course, the lesson plan is made by tutor before getting to the online class. This is in line with Permendiknas (as cited in Sagita, 2017) Learning activities describe the actual situation in an implementation of learning. The learning activities are divided into three stages, namely 1) introduction, 2) main activity, and 3) closing. The researcher found that three stages of learning activities in English Boxes' lesson plan, especially in English for kids class.

In general, before making lesson plan, there is a syllabus which is the reference for making lesson plans. According to (NASIONAL, n.d.) Syllabus is a program that is carried out for a fairly long period of time (one semester) which is a reference in developing lessons which are programs for a shorter period of time. The syllabus is basically a macro program that must be translated into more detailed learning programs, namely the lesson plan. In this case, the syllabus is important to be used as a reference in making lesson plans. But in fact, the English Box Course did not have syllabus. The researcher believes that in conducting learning in the English box, it doesn't matter if you don't have a syllabus, because the lesson plan is in accordance with the function of the syllabus. The second activity in planning was media. The function of learning media aims to attract more students' attention so that it can foster students' learning motivation. Based on the data taken from observation, the tutor used zoom premium from that have provided by the course because it can be longer. The tutor prepared an interesting powerpoint to deliver the vocabulary subject that will be taught in the class.

\section{b. Process}

The first activity in preliminary was apperception. Before the tutor going to do the apperception, the day before the students' get to the learning activities, the 
tutor shared the zoom link. Apperception means everything that was the basis for accepting new ideas. In general, the function of apperception in learning activities aims to bring their world into the tutors' world. That is linking what has been known or experienced with what will be learned. It aims to establish an interactive and communicative relationship with students while doing learning. The results obtained from this apperception is, that students more enthusiastic and more focused in participating in the learning process.

In the implementation of Total Physcal Response (TPR) method, In the teaching and learning process used the Total Physical Response method, researchers found one main activity carried out by teachers and student, namely, Practice using commands (Imperative Dril). Imperative drill was the main activity that teachers do in the teaching-learning process. Exercise was useful for obtaining physical movement and activity from students. The teacher gave instructions to several students and then exemplify and practice it in front of students so that students can understand the instructions given and can follow it. Besides that, according to the research finding above, conclude the three main principles. This is in line with the opinion from Asher (as cited in (Dwiastuty et al., 2016) put forward three main principles TPR system, namely: (1) speaking activities begins after students understand spoken language instructed by the teacher (2) Understanding is achieved through verbal instructions spoken by the teacher in the form of imperative or imperative sentence (3) Student strived to show readiness speak.

The implementation of the Total Physical Response method was very simple. Students only do what was instructed by the tutor or their classmate. The most important thing in implementing the Total method Physical Response was the tutor helping students to be directly involved in the activities of the Total Physical Response method, so that students can do what they have heard. Based on the interview, the tutor gave the basic vocabulary. Start from Animal, part of body, body movement, sport and many more. In implementing TPR method, the tutor asked the students to follow the tutor instruction by using action and sounds. Like when the tutor taught the student about vocabulary of animal, the tutor asked the student to demonstrate the animal.

\section{c. Evaluation}

The tutor has evaluated the students' understanding of vocabulary each day. The tutor checked their understanding of learning process, but sometimes the tutor checked the students' understanding at the end of class by giving a guessing game. Based on the interview and the observation that the researcher have done, tutors evaluate students' abilities at the end of the lesson. Through evaluation, the tutor determines the success of learning in each teaching and learning process. In this case, the evaluation function is in accordance with opinion from (Arikunto, 2021) Evaluation is an activity to collect information about the work of something, which is then used to determine the right alternative in making decisions. 
Jurnal Pendidikan Bahasa Inggris Proficiency, Vol 4 No 1 Jan 2022

\section{2) The Students' Response of The implementation of Total Physical Response ( TPR) method to teach vocabulary in E-Learning}

Based on observation and interview, the two students have a good response in learning vocabulary through E-Learning. When the researcher did the observations, three students took part in the learning-teaching process. At the end of teaching-learning process, the researcher saw that the student has any expression in receiving the material which means it can be good or bad. In the other side, the young learner felt that his understanding increased. As stated below:

“...(translated) How do you feel when joining Ms. Harum class?” Asked the researcher

"...(translated) I have new vocabulary and I like the picture. I enjoy and I'm happy", answered L3 to the tutor.

"...(translated) how about you, L2? " asked the tutor to L2

“...(translated) I also get many new vocabularies and now I know. I feel happy”

This could be said that the students' response in the tutor method and the way tutor delivering the material through $\mathrm{E}$ - Learning was great and so far, the young learner feel that it is a good way to receive new vocabulary, learning and understanding the vocabularies. In the other said, it can be proven by an interview between the researcher and students.

“....(translated) In your opinion, does learning vocabulary using the TPR method make it easier or difficult for you?" asked the researcher to young learners.

“...(translated) for me, ms. Harum has a great way to teach me. I feel fun even sometimes I little bit difficult to remember the vocabulary. but I like to follow Ms. Harums' instruction" answered the L2

"...(translated) hmmm.. sometimes it is really hard for me to memorize the vocabulary. But, how ms. Harum likes to smile." Answered the L3

Based on the students' response toward the implementation of Total Physical Response (TPR) method to teach vocabulary in E- Learning were:

1. The students feel that it was very fun when the tutor implementing TPR method in teaching vocabulary through zoom. It is in line with the opinion from Pinter (as cited in Ma'rifat, 2017), young learners enjoy fantasy, imagination, and movement. So, physical activity is an appropriate method. On the other hand, TPR method can increase the attention of students to be interested learning process.

2. The young learner felt that it is a good way to learn and it can improve their English skill. The way of teaching will become one factor also in the learning teaching process. This is in line with the opinion from (Masni, 2017) Regarding increasing the effectiveness of learning through teaching method, it is concluded that in the delivery of subject matter, a teacher must be able to determine what method is appropriate in accordance with the material to be delivered so that student learning achievement will be achieved according to the objectives. So, the student gave the positive response from that. 
Jurnal Pendidikan Bahasa Inggris Proficiency, Vol 4 No 1 Jan 2022

3. It can be primary necessary to become the main role to manage the class. So, it can be said the young learner response are good at this kind of implementing TPR method. It can be method to the other tutors who wants to teach vocabulary to young learner through Zoom. From the students' response, the researcher conclude that it is in line with the opinion of Suhendan (as a cited in Hafidah \& Dewi, 2019) the most suitable learning method for children is the TPR method (Total Physical Response).

\section{3) Discussion about Assessment of The implementation of Total Physical Response (TPR) to teach vocabulary in E-Learning}

The assessment stage is carried out during the learning process. In this research, the tutor used two kinds of test, those are oral test and action test. In doing the test, there are three aspects must be reached, namely (1) coordination of commands, (2) speech and (3) movement (action) and trying to teach language through physical activity (motor). The first is oral test. An oral test is a test which the tutor asked directly the questions to the students. Two aspects of this test were the coordination of commands and speech. The tutor assesed these points using an oral test. The stage of oral test in the implementation of Total Physical Response (TPR) method was where the tutor asked students to respond using sound, such as in animal vocabulary material. The tutor gave commands to students to imitate animal sounds and the student gave the response or answer correctly, which means that the student understands the vocabulary that has been given. All the observation that researcher told before, has evidence such as the conversation between students and tutors below:

“...(Translated) How does the cat sound?” asked the tutor to the learner.

"miaw..miaw.." answered the learner.

"...(translated) how does the chicken sound?"

"kukkuruyukkk..."

"....(translated) what sound is this, roaarrrrrr" asked the tutor to learner

"lion Ms or tiger Ms" answered the learners.

The second test is action test. An action test is a test in which the students give the response or answer in the form of concrete action. The tutor did the observations of the students' behavior in assessing action tests. The aspect should be reached were movement (action) and students' response through physical activity (motor). This was conversations between tutors and students:

“...(translated) okay, L2 how does the rabbit movement?" asked the tutor

Students respond by practicing how the rabbit jumps

On the other hand, the tutor also asked the students to demonstrate one of the animals, then their friends were asked to guess. From this, the tutor asses students' understanding of vocabulary on that day. Based on the results of the data, the tutor conducted two tests, namely an oral test and a movement test. In conducting an oral test, the tutor will provide instructions. This finding is in line with the opinion from (Astutik \& Aulina, 2017) The tutor determines the value of students' activeness and accuracy in responding in speech. When the tutor does the action test, it means that 
the tutor determined the value of the accuracy of the student's response through the Movement. It is in line with opinion of Harmer ( as cited in Oktaviyani, 2015) suggests that the characteristics of children when learning is that they don't just focus on what taught, but also learn many things at the same time, such as taking information from the surroundings such as seeing, listening, and touching are equally important in the process understanding.

From the research finding above, the researcher found the theory that in line with the opinion from Tarigan ( as cited in Astutik \& Aulina, 2017) TPR method understanding and memory are obtained well through the students' body movements in answering or responding to the tutors' commands. The two tests above, are the goals of Asher (as cited in Masitoh et al., 2011), he argues that direct speech to a child or student contains a command, and then the child or student will respond to the physical before they start to produce a verbal response. It means, verbal or physical responses determine students' understanding of the learning carried out using the TPR method.

\section{CONCLUSION}

From the result and discussion, the conclusions of this research can be drawn as follows:

1) The implementation of Total Physical Response (TPR) method in the term of planning, process and evaluation of teaching vocabulary through $\mathrm{E}$ - Learning: (a) There are two activities in the planning, those are lesson plan and media preparation. The tutor prepared zoom meeting and make the PowerPoint.

(b) There are three activities in the process of implementation of Total Physical Response (TPR) method to teach vocabulary in E-Learning. Those are: 1) preliminary; greeting, checking the attendance list, and pray. 2) main activity; is started when the tutor shared the PowerPoint on the screen, the tutor do the drilling, the tutor played video on YouTube, Question and Answer session and Assess the student. 3) Closing activity; the tutor asked the difficulty to student and give the motivation.

(c) The evaluation is taken in general of learning-teaching process. The result of assessment use for giving the evaluation. The evaluation aims to make sure understanding of the students.

2) There are two responses of the implementation of Total Physical Response (TPR) method in teaching vocabulary through E-Learning. 1) students gives positive response in implementing The Total Physical Response. The student feel happy and fun, and 2) student feel comfortable with the media that has prepared by the tutor.

3) There are two kinds of the assessment of the implementation of Total Physical Response (TPR) method in teaching vocabulary through E-Learning. Those are, 1) oral test, and 2) movement test. The use of both tests in assessment can measure the success of the implementation of Total Physical Response (TPR) method. 
Jurnal Pendidikan Bahasa Inggris Proficiency, Vol 4 No 1 Jan 2022

Based on the conclusion above, the researcher give some suggestions as follows:

1) For owner English Box course, the owner should be able to develop the TPR method and provide innovation to tutors regarding the TPR method.

2) The future researchers, the tutor should have syllabus so that learning is more effective and more focused for the next learning project and also the tutor should make more interesting learning media so that student more enjoy to learn English.

3) For the further researchers, the number of participants were only two, so it did not describe the success of the TPR method. Thus, for future researchers, it is hoped that can do this research with more participants, so that it can describe more clearly the success of TPR and also the results of this study are expected to be a reference and input for conducting more in-depth research on TPR teaching method.

\section{REFERENCES}

Al Hosni, S. (2014). Speaking difficulties encountered by young EFL learners. International Journal on Studies in English Language and Literature (IJSELL), 2(6): 22-30.

Apriliyanti, D. L. et al. (2019). Pelatihan Metode TPR Untuk Meningkatkan Kemampuan Berbicara Dan Kreativitas Siswa di Tingkat SMP, Desa Jalancagak, Kabupaten Subang. Abdimas Siliwangi, 2(2): 155-165.

Arikunto, S. (2021). Dasar-dasar Evaluasi Pendidikan Edisi 3. bumi aksara.

Astutik, Y., \& Aulina, C. N. (2017). Metode Total Physical Response (TPR) Pada Pengajaran Bahasa Inggris Siswa Taman Kanak-kanak. Metode Total Physical Response (TPR) Pada Pengajaran Bahasa Inggris Siswa Taman KanakKanak, 17(2): 9-23.

Hafidah, R., \& Dewi, N. K. (2019). Metode TPR (Total Physical Response) Dalam Pembelajaran Bahasa Inggris Pada Anak Usia Dini. Seminar Nasional Pendidikan Dan Pembelajaran 2019, 393-399.

Herliandry, L. D. et al. (2020). Pembelajaran pada Masa Pandemi Covid-19. JTPJurnal Teknologi Pendidikan, 22(1): 65-70.

Masitoh, D. et al. (2011). Penggunaan Metode TPR (Total Physical Response) Sebagai Upaya Meningkatkan Keterampilan Berbicara Bahasa Inggris Siswa Kelas V SDN Samirono Yogyakarta. Pelita-Jurnal Penelitian Mahasiswa $U N Y, 1$.

Masni, H. (2017). Strategi Meningkatkan Motivasi Belajar Mahasiswa. Jurnal Ilmiah Dikdaya, 5(1): 34-45.

Nasional, D. P. (n.d.). Bahan Pendidikan dan Latihan Profesi Guru Dalam Jabatan Pengawas Sertifikasi Guru Rayon 11 Universitas Negeri Yogyakarta.

Oktaviyani, A. (2015). Evaluasi Program Pembelajaran Bahasa Inggris Kelas English For Children di English Smart Bandar Jaya. Universitas Lampung.

Rokhayani, A. (2010). Motivating Students of Young Learners through Story Telling in English Class. TEYLIN 2: From Policy to Classroom, 36-44.

Suharsimi, A. (2011). Prosedur Penelitian Suatu Pendekatan Praktek (4th ed.). Rineka Cipta. 